\title{
Intercropping maize and succession crops alters the weed community in common bean under no-tillage ${ }^{1}$
}

\author{
Victor D’Amico-Damião ${ }^{2}$, Arthur Arrobas Martins Barroso ${ }^{3}$, Pedro Luis da Costa Aguiar Alves ${ }^{2}$, Leandro Borges Lemos ${ }^{4}$
}

\section{ABSTRACT}

Crop rotation is critical in the management of herbicideresistant weed species. This study aimed to evaluate the effect of intercropping systems of maize with brachiaria or crotalaria on qualitative and quantitative parameters of the weed seedbank, along the succession of pearl millet, maize and common bean. Moreover, the effect of these crop rotation systems on the selection of specific weed species of the seedbank was also evaluated. The experimental design was randomized blocks, with four replications. The treatments were represented by three cropping systems in succession: pearl millet, single maize, common bean; pearl millet, maize intercropped with brachiaria, common bean; pearl millet, maize intercropped with crotalaria, common bean. The following phytosociological indexes were calculated: density, frequency and relative importance, diversity and equitability. The grain yield of maize and common bean were also quantified. Twenty-three weed species were identified, divided into 12 families, highlighting the Poaceae one, with the most important being Alternanthera tenella, Commelina benghalensis, Eleusine indica and Phyllanthus tenellus. The cropping system with single maize presented a lower density and diversity of weeds, but with a high selection of $E$. indica. The intercropping systems in the previous crop, as a guarantee of a higher weed diversity, could be use as alternative tools, different from the herbicides, to control weeds and improve the common bean yield. Regarding the weed control in the common bean, Crotalaria spectabilis presented better results in the previous maize-intercropping system than Urochloa ruziziensis.

KEYWORDS: Crotalaria spectabilis, Phaseolus vulgaris, Urochloa ruziziensis, seedbank.

\section{INTRODUCTION}

The no-tillage system is a globally consolidated production model. The principles of crop rotation,

\section{RESUMO \\ Consorciação de milho e culturas de sucessão altera a comunidade de plantas daninhas em feijão comum sob plantio direto}

A rotação de culturas é essencial no manejo de espécies de plantas daninhas resistentes a herbicidas. Objetivou-se avaliar o efeito de sistemas consorciados de milho com braquiária ou crotalária nos parâmetros qualitativos e quantitativos do banco de sementes de plantas daninhas, ao longo da sucessão de milheto, milho e feijão. Além disso, o efeito desses sistemas de rotação de cultura na seleção de espécies específicas de plantas daninhas do banco de sementes também foi avaliado. O delineamento experimental foi em blocos casualizados, com quatro repetições. Os tratamentos foram representados por três sistemas de cultivo em sucessão: milheto, milho solteiro, feijoeiro; milheto, milho consorciado com braquiária, feijoeiro; milheto, milho consorciado com crotalária, feijoeiro. Foram calculados os seguintes índices fitossociológicos: densidade, frequência e importância relativa, diversidade e equitabilidade. As produtividades de grãos de milho e de feijão também foram quantificadas. Foram identificadas 23 espécies de plantas daninhas, divididas em 12 famílias, com destaque para Poaceae, sendo as mais importantes Alternanthera tenella, Commelina benghalensis, Eleusine indica e Phyllantus tenellus. O sistema de cultivo com milho solteiro apresentou menor densidade e diversidade de plantas daninhas, com elevada importância para $E$. indica. Os sistemas de consórcio na safra anterior, como garantia de maior diversidade de plantas daninhas, podem ser utilizados como ferramentas alternativas, diferentes dos herbicidas, para controlar plantas daninhas e melhorar a produtividade do feijoeiro. Em relação ao controle de plantas daninhas no feijoeiro, Crotalaria spectabilis apresentou melhores resultados no sistema consorciado de milho anterior do que Urochloa ruziziensis.

PALAVRAS-CHAVE: Crotalaria spectabilis, Phaseolus vulgaris, Urochloa ruziziensis, banco de sementes.

straw production and no-tillage ensure the sustainability of the agroecosystem (Gomes Junior \& Christoffoleti 2008, Cardoso et al. 2017, Vargas et al. 2017). The benefits to the growing environment by

${ }^{1}$ Received: Aug. 25, 2020. Accepted: Dec. 07, 2020. Published: Dec. 16, 2020. DOI: 10.1590/1983-40632020v5065244.

${ }^{2}$ Universidade Estadual Paulista, Faculdade de Ciências Agrárias e Veterinárias, Departamento de Biologia Aplicada à Agropecuária, Jaboticabal, SP, Brasil.E-mail/ORCID: damicodamiao@gmail.com/0000-0001-9497-7063, pl.alves@unesp.br/0000-0003-2348-2121.

${ }^{3}$ Universidade Federal do Paraná, Setor de Ciências Agrárias, Curitiba, PR, Brasil. E-mail/ORCID: arrobas@ufpr.br/0000-0001-7687-1396.

${ }^{4}$ Universidade Estadual Paulista, Faculdade de Ciências Agrárias e Veterinárias, Departamento de Produção Vegetal, Jaboticabal, SP, Brasil.E-mail/ORCID: leandro.lemos@unesp.br/0000-0003-1781-1267. 
using these fundamentals are remarkable, promoting a greater biodiversity and favoring the soil biological, physical and chemical attributes. In addition, the natural control of agricultural pests, such as insects and diseases, as well as weed suppression, enables the long-term reduction in the use of agricultural inputs and promotes an increased yield of crops of commercial interest (Murphy et al. 2006, Bergtold et al. 2017). However, management practices applied in the no-tillage system, such as choosing the species for intercropping and rotation, the amount of straw produced and the type of applied herbicide, can modify the weed seedbank dynamics in different cropping systems (Cardina et al. 2002). In situations of high weed density, the use of forage species, such as Urochloa ruziziensis, promotes over $80 \%$ of soil cover and suppresses more than $90 \%$ of the weed community, if compared to fallow (Borges et al. 2014, Galvan et al. 2015).

For this end, intercropping gramineous and leguminous plants, for example, allows to reduce the availability of resources that would potentially be used by weeds (Martin-Guay et al. 2018). Moreover, depending on the type of intercropping, the proportion of weeds used in the row and inter-row could increase the interspecific competition (BybeeFinley et al. 2017). The plant architecture and high initial growth rate are factors that also benefit the crop control through weed competition and can reduce the weed biomass in more than $50 \%$ (Teixeira et al. 2009, Mosjidis \& Wehtje 2011).

In this context, cropping systems of maize intercropped with gramineous and leguminous plants have been highlighted to the better quality of the no-tillage system (Martin-Guay et al. 2018, D'Amico-Damião et al. 2020). Although leguminous plants benefit the cropping systems by nitrogen fixation, gramineous plants display a greater pressure on the weed seedbank emergence, because a rapid initial development and high biomass production are showed by these plant families, being determining factors for a high weed suppression (Bybee-Finley et al. 2017). In addition, maize intercropped with brachiaria (U. brizantha) could produce more than $7,000 \mathrm{~kg} \mathrm{ha}^{-1}$ of straw, when compared to single maize, resulting in a weed control index of $95 \%$ (Borghi et al. 2008). Maize-leguminous intercropping is also a strategy for weed control. In addition to promoting straw production, leguminous plants exhibit allelochemical exudation in the soil capable of suppressing from nematodes (BybeeFinley et al. 2017) to weeds (Javaid et al. 2015). Allelopathic suppression of Eleusine indica and Amaranthus hybridus has been reported by Crotalaria juncea residues, which reduced the germination and development of these weeds species (Adler \& Chase 2007).

In this way, integrated crop management systems mitigate the use of herbicides, according to no-tillage system requirements (Bergtold et al. 2017), allowing the use of long-term efficient strategies for weed control (Gomes Junior \& Christoffoleti 2008). In fact, the dynamics of weed seedbanks is strongly regulated by the applied management (Murphy et al. 2006, Cardoso et al. 2017, Vargas et al. 2017). However, intrinsic factors of weed species, such as morphological (seed size, shape and dispersal) and physiological (germination, dormancy type and resistance) characteristics also interact in the phytosociology of the weed community (Cardina et al. 2002, Masin et al. 2006, Feng et al. 2015, Darmency et al. 2017).

Therefore, monitoring the soil weed seedbank dynamics is essential for an integrated weed control in the no-tillage system (Gomes Junior \& Christoffoleti 2008), considering the size, period and depth of sampling, which are susceptible to temporal and spatial variations in field experiments (Webster et al. 2003, Chauhan \& Johnson 2009). As observed by Lima et al. (2014), the weed community changes during the cover crop development cycle, and the species with the highest importance value are controlled, as verified for E. indica at 90 days after sowing (DAS) of U. ruziziensis and at 135 DAS of Crotalaria spectabilis. Indeed, the results presented in the literature highlight the lack of phytosociological researches aiming to define integrated weed control strategies for the different cropping regions under no-tillage (Bybee-Finley et al. 2017, Vargas et al. 2017). Thus, this study aimed to evaluate the effect of maize intercropped with brachiaria or crotalaria on the phytosociological parameters of the weed seedbank along the succession of pearl millet, maize and common bean, under no-tillage.

\section{MATERIAL AND METHODS}

The experiment was carried out in the 2015/2016 crop season, in an area located in the São Paulo state, Brazil ( $21^{\circ} 14^{\prime} 59^{\prime \prime} \mathrm{S}$ and $48^{\circ} 17^{\prime} 13^{\prime \prime} \mathrm{W}$, 
at an average altitude of $565 \mathrm{~m}$ ). The soil of the experimental area was classified as an Eutrophic Red Oxisol of clayey texture (USDA 2014), with the following chemical characteristics $(0-20 \mathrm{~cm})$ : $\mathrm{pH}\left(\mathrm{CaCl}_{2}\right)$ : 5.6; OM: $24 \mathrm{~g} \mathrm{dm}^{-3} ; \mathrm{P}$ (resin): $41 \mathrm{mg} \mathrm{dm}^{-3}$; $\mathrm{H}+\mathrm{Al}: 28 \mathrm{mmol}_{\mathrm{c}} \mathrm{dm}^{-3} ; \mathrm{K}^{+}: 5.7 \mathrm{mmol}_{\mathrm{c}} \mathrm{dm}^{-3}$; $\mathrm{Ca}^{2+}: 30 \mathrm{mmol}_{\mathrm{c}} \mathrm{dm}^{-3} ; \mathrm{Mg}^{2+}: 14 \mathrm{mmol}_{\mathrm{c}} \mathrm{dm}^{-3} ; \mathrm{SB}$ : $50 \mathrm{mmol}_{\mathrm{c}} \mathrm{dm}^{-3}$; CEC: $78 \mathrm{mmol}_{\mathrm{c}} \mathrm{dm}^{-3}$; V: $64 \%$. In the years prior to the implementation of the experiment, the area was cultivated with annual grain crops in a conventional tillage system, highlighting the succession of soybean and maize as summer cash crops.

The used experimental design was randomized blocks, with four replications. The treatments were represented by the succession of crops in three distinct maize cropping systems: pearl millet, single maize, common bean; pearl millet, maize intercropped with $U$. ruziziensis, common bean; pearl millet, maize intercropped with C. spectabilis, common bean. Each experimental plot $(2.7 \times 25 \mathrm{~m})$ had four rows for maize and six for common bean.

The pearl millet (Pennisetum americanum L.) sowing (September 21, 2015), cultivar ADR-300, occurred mechanically, with row spacing of $0.45 \mathrm{~m}$, using $14 \mathrm{~kg} \mathrm{ha}^{-1}$ of pearl millet seeds desiccated using 1,300 $\mathrm{g} \mathrm{ha}^{-1}$ of glyphosate (Zapp QI 620, Syngenta, Paulínia, Brazil) and $108 \mathrm{~g} \mathrm{ha}^{-1}$ of clethodim (Select 240 EC, Arysta, Salto de Pirapora, Brazil), at 56 DAS. The pearl millet straw dry matter was $5.1 \mathrm{Mg} \mathrm{ha}^{-1}$ at ten days prior to the maize sowing.

The maize hybrid AS1633 PRO2 was mechanically sown (November 28, 2015) in the no-tillage system, with row spacing of $0.90 \mathrm{~m}$ and population density of 60,000 plants $\mathrm{ha}^{-1}$. The intercroppings were sown between the maize rows, in a double inter-row mode, spaced $0.22 \mathrm{~m}$ from the maize rows. The used seeds were $10 \mathrm{~kg} \mathrm{ha}^{-1}$ for brachiaria and $12 \mathrm{~kg} \mathrm{ha}^{-1}$ for crotalaria. The single and intercropped maize cropping systems were sowing fertilized with $240 \mathrm{~kg} \mathrm{ha}^{-1}$ of the formulation 08-28-16 ( $\mathrm{N}, \mathrm{P}_{2} \mathrm{O}_{5}$ and $\mathrm{K}_{2} \mathrm{O}$, respectively). Topdressing fertilization was performed with the application of $200 \mathrm{~kg} \mathrm{ha}^{-1}$ of the formulation 30-00-10 applied at the maize $\mathrm{V}_{6}$ phenological stage.

During the maize cycle, the accumulated rainfall was $1,165.4 \mathrm{~mm}$. The weed chemical management was performed at the maize $\mathrm{V}_{6}$ phenological stage, with 1,300 $\mathrm{g} \mathrm{ha}^{-1}$ of glyphosate (Zapp QI 620, Syngenta, Paulínia, Brazil) for single maize and 1,500 $\mathrm{g} \mathrm{ha}^{-1}$ of atrazine (Atrazine $500 \mathrm{SC}$, Nortox, Arapongas, Brazil) for maize intercropped with brachiaria. For maize intercropped with crotalaria, no chemical weed control was performed, according to recommendations by Nogueira (2015).

The maize harvest was performed on May 05, 2016, with the maize ears harvested manually in the useful area of each plot to quantify the maize grain yield in each cropping system ( $\mathrm{Mg} \mathrm{ha}^{-1} ; 13 \%$ wet basis). The experimental area was desiccated on June 11,2016 , using 1,300 $\mathrm{g} \mathrm{ha}^{-1}$ of glyphosate (Zapp QI 620, Syngenta, Paulínia, Brazil) and $108 \mathrm{~g} \mathrm{ha}^{-1}$ of clethodim (Select 240 EC, Arysta, Salto de Pirapora, Brazil). The straw amounts produced in each cropping system, at 15 days prior to the common bean sowing, were 7.5 (single maize), 10.5 (maize intercropped with brachiaria) and 10.0 (maize intercropped with crotalaria) $\mathrm{Mg} \mathrm{ha}^{-1}$.

The mechanical sowing of common bean in the winter crop was carried out on June 21, 2016, in the no-tillage system, using the IAC Alvorada cultivar, in a row spacing of $0.45 \mathrm{~m}$ and sowing density of 15 seeds $\mathrm{m}^{-1}$ (80\% germination). The common bean was sowing fertilized with $200 \mathrm{~kg} \mathrm{ha}^{-1}$ of the formulation 04-20-20. For the common bean, the weed control was carried out in the total area, at the $\mathrm{V}_{2}$ and $\mathrm{V}_{3}$ phenological stages, with the application of 600 and $28 \mathrm{~g}$ a.i. ha $^{-1}$ of bentazon + imazamox, respectively (Amplo, Basf, Guaratinguetá, Brazil), and $100 \mathrm{~g}$ a.i. ha $^{-1}$ of tepraloxidim (Aramo 200, Basf, Guaratinguetá, Brazil).

At the $\mathrm{V}_{4-4}$ phenological stage, the cover fertilization was carried out in the common bean crop using $100 \mathrm{~kg} \mathrm{ha}^{-1}$ of $\mathrm{N}$ via urea. The water was supplied to the crop via conventional spraying irrigation, with $10-15 \mathrm{~mm}$ per irrigation shift, according to the crop requirements. The common bean grains were harvested on September 29, 2016, by manual plant harvesting, within each plot, followed by mechanical trail. The grains were cleaned and weighed, allowing to estimate the grain yield ( $\mathrm{Mg} \mathrm{ha}^{-1}$; $13 \%$ wet basis).

The characterization and quantification of the weed seedbank community were performed from soil collection using an auger, at a depth of 0-0.2 $\mathrm{m}$, to evaluate the weed seedbank and the weed emergence flow. The samples were collected in four moments: i) fallow (initial caractherization before the experiment installation; September 15, 2015); ii) pearl millet harvest (November 7, 2015); 
iii) maize harvest (April 28, 2016); iv) common bean harvest (October 10, 2016). We randomly collected four samples (replications per plot) composed of four subsamples each.

The weed seedbank was determined using $1.0 \mathrm{~kg}$ of soil per plot, following the methods by Buhler \& Maxwell (1993) for separation of organic material and mineral fraction. Subsequently, the weed seeds were identified and quantified using a loupe (Kissmann \& Groth 1999). For the weed emergence flow, which evaluates the germination percentage of non-dormant seeds in a given area, $1.0 \mathrm{~kg}$ of soil was collected from each sample, placed in a plastic tray with internal dimensions of $0.217 \times 0.147 \times 0.068 \mathrm{~m}$, and conducted in a greenhouse with daily irrigation. The weed emergence flow was determined during 30 days, period in which the seedlings were daily identified and counted (Kissmann \& Groth 1999).

From the identification and counting of the weed species, the phytosociological study of the weed community present in each cropping system was performed by evaluating the seed total density (seeds $\mathrm{m}^{-2}$ ) and the adapted relative importance (\%), considering the relative frequency and the relative density factors for both the weed seedbank and weed emergence flow (Mueller-Dombois \& Ellemberg
1974). The Shannon-Wiener diversity (H') and Pielou equitability (E') indices were also determined (PintoCoelho 2000). The maize and common bean yield results were subjected to analysis of variance, and the averages compared by the Tukey test at $5 \%$ of probability, using the AgroEstat ${ }^{\mathrm{TM}}$ software.

\section{RESULTS AND DISCUSSION}

During the conduction of the experiment, 23 weed species were identified and divided into 12 families, especially Poaceae (7 species), Asteraceae (3 species) and Amaranthaceae, Brassicaceae and Solanaceae, with 2 species each. The remaining families were represented by one species. Considering these species, $34.8 \%$ were monocotyledonous and $65.2 \%$ dicotyledonous (Table 1).

For the pearl millet crop, the density of seeds present in the weed seedbank increased in relation to that in the initial characterization (fallow) of the experimental area (Figure 1A). The density of emerged seedlings showed no differences (Figure 1B). Although the unrestricted development of weeds in the area increases the seed production and seed dispersal during fallow (Borges et al. 2014, Galvan et al. 2015), the emergence of these

Table 1. Family, species and class of weeds identified in the experimental area at the following periods: fallow (initial area caractherization), pearl millet (Pennisetum glaucum), maize (Zea mays) and common bean (Phaseolus vulgaris).

\begin{tabular}{|c|c|c|}
\hline Family & Species & Class \\
\hline Amaranthaceae & $\begin{array}{l}\text { Alternanthera tenella } \\
\text { Amaranthus spp. }\end{array}$ & Dicotyledon \\
\hline Asteraceae & $\begin{array}{l}\text { Acanthospermum hispidum } \\
\text { Parthenium hysterophorus } \\
\text { Synedrellopsis grisebachii }\end{array}$ & Dicotyledon \\
\hline Brassicaceae & $\begin{array}{l}\text { Lepidium virginicum } \\
\text { Raphanus raphanistrum }\end{array}$ & Dicotyledon \\
\hline Commelinaceae & Commelina benghalensis & Monocotyledon \\
\hline Euphorbiaceae & Chamaesice hirta & Dicotyledon \\
\hline Faboideae & Indigofera hirsuta & Dicotyledon \\
\hline Malvaceae & Sida spp. & Dicotyledon \\
\hline Phyllantaceae & Phyllanthus tenellus & Dicotyledon \\
\hline Poaceae & $\begin{array}{l}\text { Cenchrus echinatus } \\
\text { Digitaria spp. } \\
\text { Eleusine indica } \\
\text { Panicum maximum } \\
\text { Pennisetum glaucum } \\
\text { Urochloa } \text { spp. }\end{array}$ & Monocotyledon \\
\hline Portulacaceae & Portulaca oleracea & Dicotyledon \\
\hline Rubiaceae & Richardia brasiliensis & Dicotyledon \\
\hline Solanaceae & $\begin{array}{l}\text { Nicandra physaloides } \\
\text { Solanum americanum }\end{array}$ & Dicotyledon \\
\hline
\end{tabular}



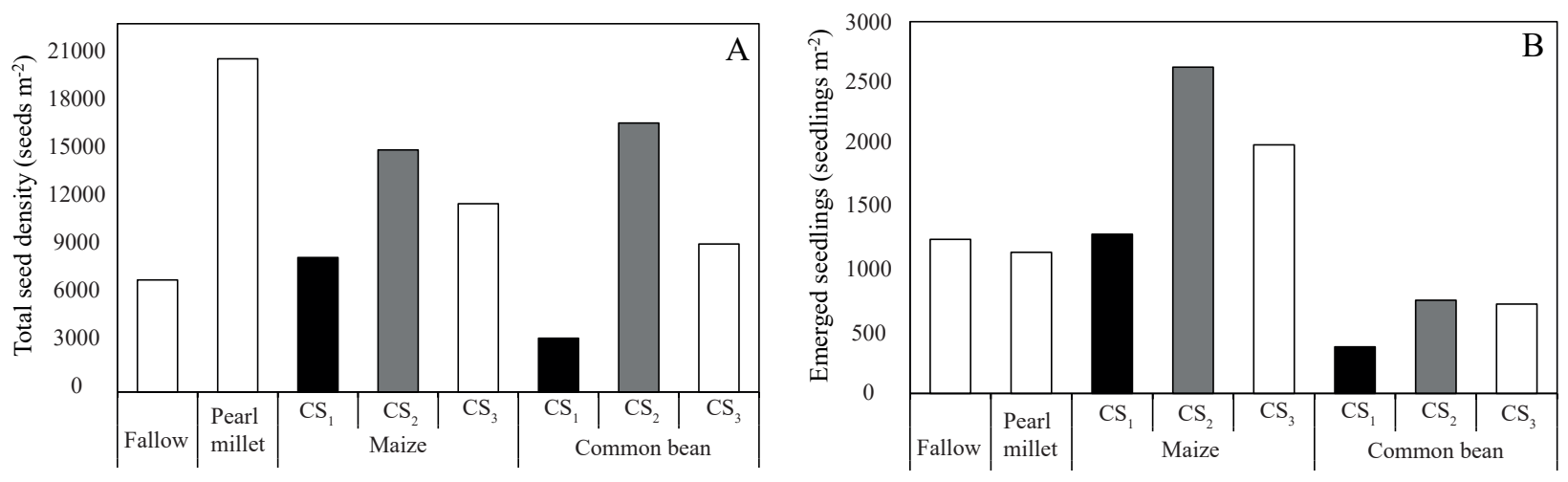

Figure 1. Total seed density (A) and emerged seedlings (B) of the weed community throughout the crop rotation in the experimental area. Average values in the area: fallow (initial area caractherization) and pearl millet (Pennisetum glaucum) harvest. Values by cropping system: maize (Zea mays) harvest and common bean (Phaseolus vulgaris) harvest. CS $_{1}$ : single maize (black bars); $\mathrm{CS}_{2}$ : maize intercropped with Urochloa ruziziensis (gray bars); $\mathrm{CS}_{3}$ : maize intercropped with Crotalaria spectabilis (white bars). Samples collection: fallow (September 15, 2015); pearl millet harvest (November 7, 2015); maize harvest (April 28, 2016); common bean harvest (October 10, 2016).

weeds could be affected by the management and the species present in the seedbank, which may be under dormancy (Chauhan \& Johnson 2009). Dormancy is a characteristic of weed aggressiveness that allows, even under ideal conditions, the stepped germination of weeds in the seedbank. Thus, the species ensures greater chances of success in the environmental establishment over time (Darmency et al. 2017).

The species with higher relative importance were the same both in the fallow and in the pearl millet (Table 2): Alternanthera tenella, Amaranthus spp. and E. indica for the seedbank; and A. tenella, Phyllanthus tenellus and Commelina benghalensis for the weed emergence flow. A. tenella, like other plants of the Amaranthaceae family, is known to be prolific. For example, a single plant can produce up to 500,000 seeds (Kissmann \& Groth 1999). However, E. indica, on average, produces fewer seeds per plant $(120,000)$ than prolific weeds. On the other hand, E. indica showed a fast initial growth and notable competitive interference with commercially important crops such as common bean (Barroso et al. 2010, Barroso et al. 2017). Although some species showed a high relative importance in the weed seedbank, the same was not observed for the weed emergence flow (Table 2), possibly due to restrictions of the seed germination (short evaluation period) methodology (Webster et al. 2003, Chauhan \& Johnson 2009), or due to the aforementioned seed dormancy of certain species, especially during the collection periods, as observed for Portulaca oleracea and E. indica, in periods of low ambient temperature (Masin et al. 2006, Feng et al. 2015), corroborating the conditions found in the sampled periods (fallow/pearl millet).

After the implementation of the maize and common bean crops, the treatments influenced the dynamics of the weed seedbank and weed emergence flow (Figures 1A and 1B). The single maize was the one that most reduced the weed seedbank and weed emergence flow in the maize and common bean crops. Supposedly, in this maize, the crop control and the frequent use of glyphosate were the main factors responsible for these results (Teixeira et al. 2009, Mosjidis \& Wehtje 2011, Bybee-Finley et al. 2017). The intercropping systems also reduced the seeds present in the soil, in relation to the effects of a fallow period; however, the reduction of total weed seedbank was smaller in the brachiaria intercropping system, when compared to the crotalaria one (Figure 1A). Despite the high weed suppression capacity by species of the Urochloa spp. genus (Borghi et al. 2008), during its reproductive stage, the seed dispersal may increase the weed seedbank (Galvan et al. 2015). A tendency to reduce the total number of seedlings emerged in the seedbank was more accentuated in the crotalaria intercropping system than in the brachiaria one (Figure 1B). Otherwise, even without herbicide application on the crotalaria intercropping system, crotalaria allelopathic mechanisms possibly contributed to the lower density of weed seedbank and weed emergence flow, when compared to the brachiaria intercropping system (Adler \& Chase 2007, Javaid et al. 2015). 
Table 2. Relative importance (\%) of the weed species identified in the seedbank and emergence flow. Average values in the area: fallow (initial area caractherization) and pearl millet (Pennisetum glaucum) harvest. Samples collection: fallow (September 15, 2015) and pearl millet harvest (November 7, 2015).

\begin{tabular}{|c|c|c|c|c|}
\hline \multirow{2}{*}{$\begin{array}{c}\text { Relative importance (\%) } \\
\text { Species }\end{array}$} & \multicolumn{2}{|c|}{ Seedbank } & \multicolumn{2}{|c|}{ Emergence flow } \\
\hline & Fallow & Pearl millet & Fallow & Pearl millet \\
\hline Acanthospermum hispidum & 3.18 & 1.66 & - & - \\
\hline Alternanthera tenella & 32.14 & 19.14 & 20.75 & 17.29 \\
\hline Amaranthus spp. & 12.20 & 15.52 & 7.29 & 5.86 \\
\hline Chamaesice hirta & 1.88 & - & - & - \\
\hline Indigofera hirsuta & - & - & - & 1.65 \\
\hline Lepidium virginicum & - & 2.00 & - & - \\
\hline Nicandra physaloides & - & 6.75 & - & - \\
\hline Parthenium hysterophorus & - & 0.91 & - & - \\
\hline Phyllanthus tenellus & 1.88 & - & 34.27 & 39.18 \\
\hline Portulaca oleracea & 10.30 & 9.63 & - & - \\
\hline Raphanus raphanistrum & - & 1.66 & - & - \\
\hline Richardia brasiliensis & - & 3.76 & 4.32 & 1.67 \\
\hline Solanum americanum & - & - & 0.99 & 1.48 \\
\hline Synedrellopsis grisebachii & - & - & 0.99 & 1.48 \\
\hline Cenchrus echinatus & 4.51 & 6.27 & - & - \\
\hline Commelina benghalensis & 1.88 & 6.21 & 11.51 & 21.49 \\
\hline Digitaria spp. & 1.50 & 1.85 & 6.54 & 4.21 \\
\hline Eleusine indica & 26.79 & 22.47 & 5.25 & 4.21 \\
\hline Panicum тахітит & 1.88 & 2.17 & 8.09 & 1.48 \\
\hline Pennisetum glaucum & 1.88 & - & - & - \\
\hline Dicotyledon & 61.57 & 61.03 & 68.61 & 68.61 \\
\hline Monocotyledon & 38.43 & 38.97 & 31.40 & 31.39 \\
\hline
\end{tabular}

Given this, it could be hypothesized that the lower presence of seeds in the soil and the lower emergence of plants could reduce the harmful effects of weeds competing with the main crop (Gomes Junior \& Christoffoleti 2008, Bybee-Finley et al. 2017). However, we observed that the maize obtained a similar yield in both cropping systems (Figure 2A) (average of $7.5 \mathrm{Mg} \mathrm{ha}^{-1}$ ). In this case, the similar maize grain yield was due to the effects from the weed communities dynamics in the fallow and pearl millet, where the same crop treatments were performed in all the studied cropping systems.

Different results were observed for commom bean, having more subtle effects on the weed
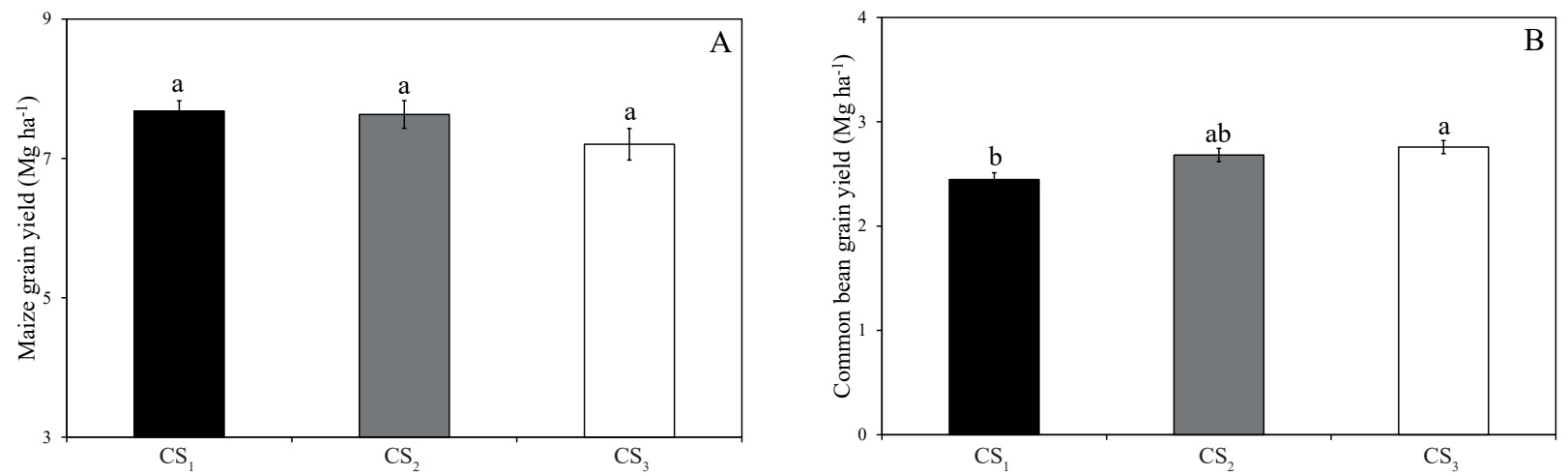

Figure 2. Grain yield of maize (Zea mays) (A) and common bean (B) (Phaseolus vulgaris) in each crop rotation system: CS, single maize (black bar); $\mathrm{CS}_{2}$ : maize intercropped with Urochloa ruziziensis (gray bar); $\mathrm{CS}_{3}$ : maize intercropped with Crotalaria spectabili (white bar). Mean values followed by equal letters do not differ by the Tukey test at $5 \%$ of probability. The bars represent \pm standard errors. Adapted from D’Amico-Damião et al. (2020). 
community, as it is a less competitive plant than maize. The highest obtained common bean grain yield was for the crotalaria intercropping system, in relation to single maize ( $12.7 \%$ higher), and the brachiaria intercropping system was intermediate to both (Figure 2B). Therefore, these observations are mainly attributed to changes in the community of weeds present in the seedbank area, due to the different managements adopted in the maize cropping (Cardina et al. 2002, Cardoso et al. 2017, Vargas et al. 2017). Here, we hypothesize that it is not only important to think about reducing the density of weeds in the field, but also to ensure that the weeds present in a specific cropping system do not interfere with the cash crop yield. In fact, many weed species can cause major changes in the crop development at low densities, such as Conyza spp. or Digitaria insularis (Trezzi et al. 2015, Gazziero et al. 2019).
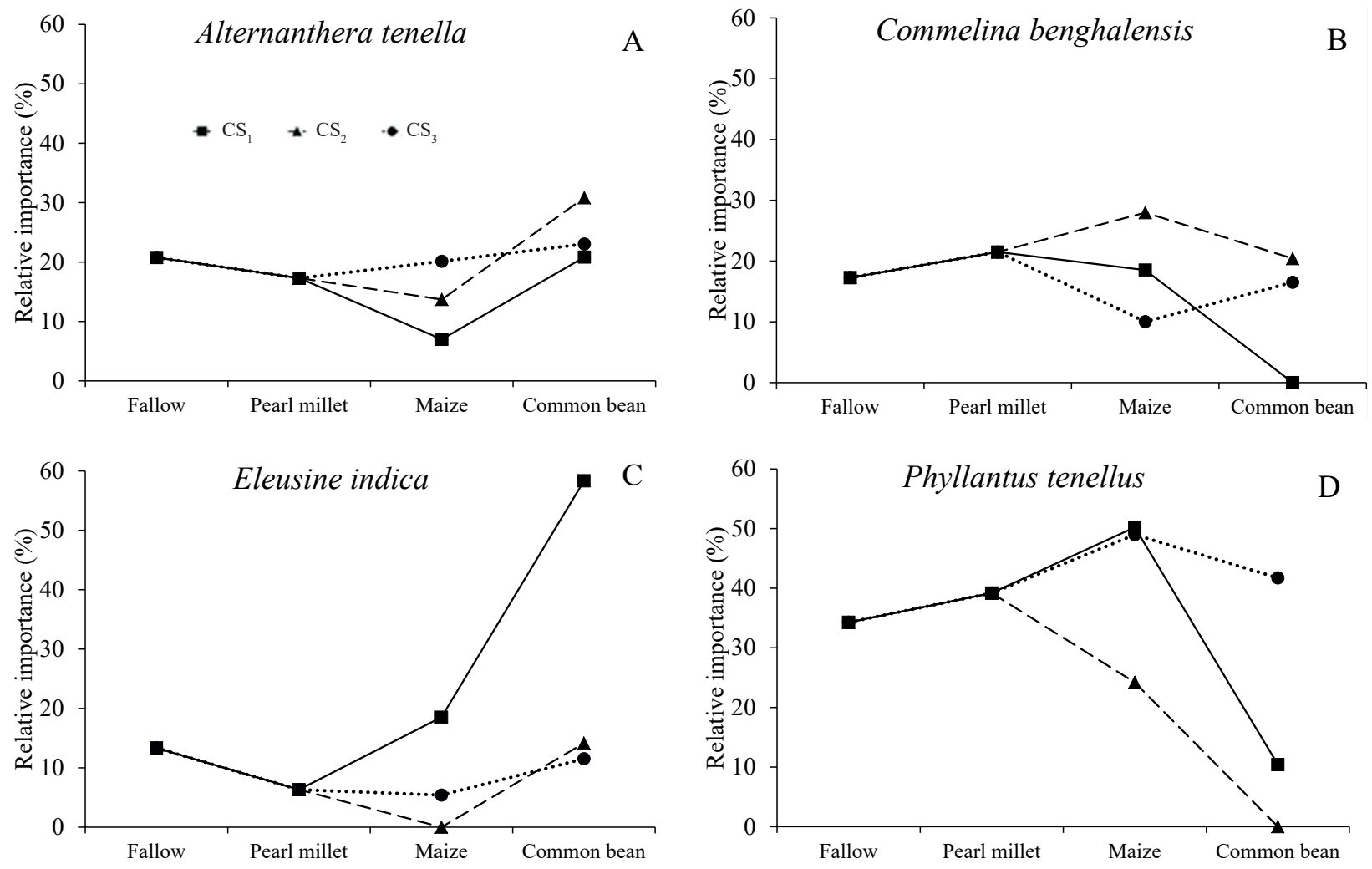

In addition, choosing crotalaria, a nitrogenfixing species (Bybee-Finley et al. 2017), may also have benefited the common bean crop development. The single maize showed a lower weed seedbank and weed emergence flow, when compared to the intercropping systems, because the species were selected to survive in the weed community. This selection is mainly highlighted for the $E$. indica species, that exhibited a higher relative importance for the weed seedbank and weed emergence flow ( $29.3 \%$ and $18.8 \%$, respectively), being strongly selected in single maize (Figure 3). Moreover, this selection can be attributed to recent reports of resistance of this species to glyphosate (Gherekhloo et al. 2017, Takano et al. 2017), which was the main chemical control strategy employed for single maize and needs further investigation (Figure 3C).

Although the common bean cultivars with semierect growth habit showed less weed interference

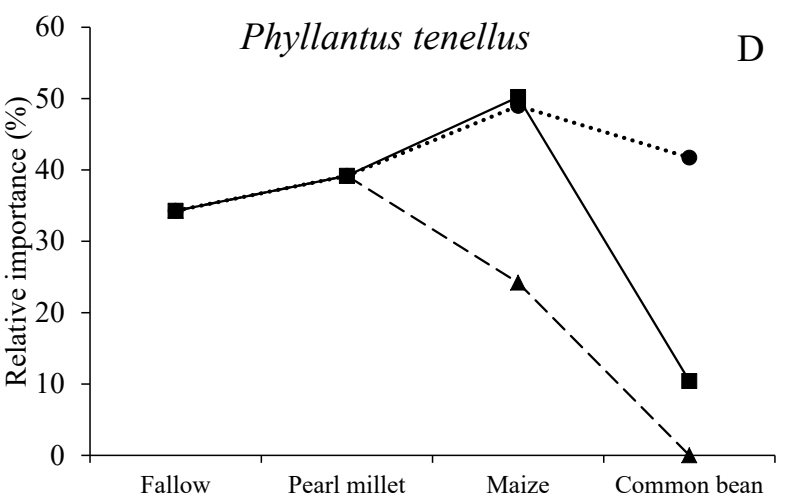

Figure 3. Emergence flow relative importance of Alternanthera tenella (A), Commelina benghalensis (B), Eleusine indica (C) and Phyllanthus tenellus (D), along the crop rotation, in the experimental area. Average values in the area: fallow (initial area caractherization) and pearl millet (Pennisetum glaucum) harvest. Values by cropping system: maize (Zea mays) harvest and common bean (Phaseolus vulgaris) harvest. $\mathrm{CS}_{1}$ (filled squares): single maize; $\mathrm{CS}_{2}$ (filled triangles): maize intercropped with Urochloa ruziziensis; $\mathrm{CS}_{3}$ (filled circles): maize intercropped with Crotalaria spectabili. Samples collection: fallow (September 15, 2015); pearl millet harvest (November 7, 2015); maize harvest (April 28, 2016); common bean harvest (October 10, 2016). 

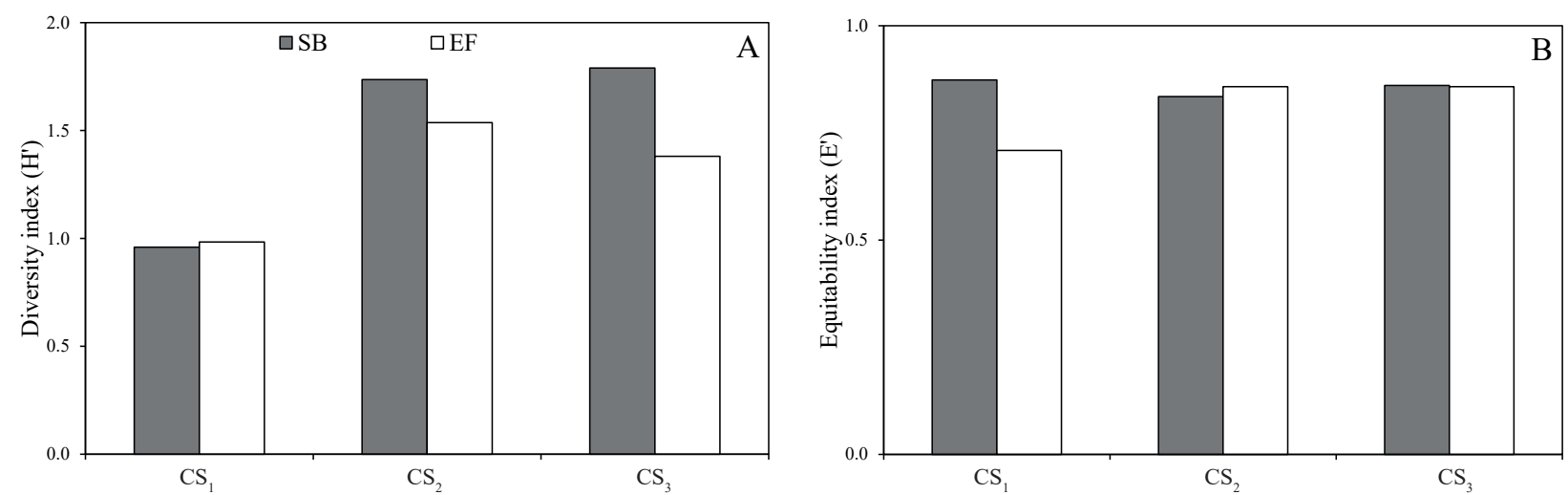

Figure 4. Shannon-Wiener diversity index (A) and Pielou equitability index (B) of the seedbank (SB; gray bars) and emergence flow (EF; white bars) of the weed community after the crop rotation of pearl millet (Pennisetum glaucum), maize (Zea mays) and common bean (Phaseolus vulgaris), in the experimental area. The data are shown as the mean values of each maize cropping system: $\mathrm{CS}_{1}$ : single maize; $\mathrm{CS}_{2}$ : maize intercropped with Urochloa ruziziensis; $\mathrm{CS}_{3}$ : maize intercropped with Crotalaria spectabilis.

(Teixeira et al. 2009), such as the IAC Alvorada cultivar (Type II/III) used in the present study, the correct sowing time and type of cropping system used are strategies to mitigate the weed competition in common bean (Barroso et al. 2010). On the other hand, the E. indica species was not selected in the brachiaria intercropping system, and the presence of brachiaria limited the development of this weed; however, A. tenella and C. benghalensis, which were controlled by glyphosate in the single maize cropping system, were selected in the brachiaria intercropping system (Figures 3A and 3B, respectively). According to the results obtained by Lima et al. (2014), the high initial importance index of the $E$. indica species was reduced to zero after 90 days from the $U$. ruziziensis sowing, what confirms the use of intercropping as a tool for herbicide resistance management. Since the highest grain yield of beans was verified when the plants were seeded on the straw of maize intercropped with C. spectabilis, we did not observe the selection of specific weed species, but only the largest presence of $P$. tenellus (Figure 3D), a weed species of low aggressiveness (Kissmann \& Groth 1999).

Therefore, the greater crop species diversity decreased the plant selection in the studied intercropped systems and benefited the common bean weed control and grain yield. In fact, the previous intercropped maize systems increased the diversity of weed species in the common bean crop (Figure 4A), while the $E$. indica species was selected in single maize due to the lower equitability of the weed emergence flow in this system (Figure 4B).
Similarly, Cardoso et al. (2017) observed a lower Shannon-Wiener diversity index with successive maize cultivation, and the weed species of highest relative importance was E. indica, when compared with other crop rotations. Indeed, the rotation of at least three crops does not affect the crop grain yield and increase the weed community diversity by reducing the weed seedbank in the notillage system (Murphy et al. 2006). On the other hand, it was found that the $C$. juncea crop rotation could increase the relative dominance and decrease the species diversity in the weed seedbank (Vargas et al. 2017). However, more accurate and long-term studies need to be considered in order to elucidate the weed emergence flow in the field (experimental area conditions), since climatic conditions could affect the seedbank dynamics. Therefore, the results presented here highlight the importance of planning the crop rotation and management through weed seedbank monitoring, in order to avoid the weed selection and improve the efficiency of herbicide use for a sustainable food production.

\section{CONCLUSIONS}

1. Maize (Zea mays) intercropping systems modify the emerged weed community and qualitatively and quantitatively alter the weed seedbank dynamics;

2. The earlier cultivation of maize intercropped with Crotalaria spectabilis increases the common bean (Phaseolus vulgaris) grain yield due to, among 
other factors, a reduced selection of specific weed species, such as Eleusine indica;

3. Different intercropping systems could be added to the weed crop control in the no-tillage system, which is a viable alternative to the replacement and/or reduction of herbicides from the system.

\section{ACKNOWLEDGMENTS}

We thank the Master's degree fellowship granted to Victor D'Amico-Damião by the Coordenação de Aperfeiçoamento de Pessoal de Nível Superior (Brazil, Capes, finance code 001).

\section{REFERENCES}

ADLER, M. J.; CHASE, C. A. Comparison of the allelopathic potential of leguminous summer cover crops: cowpea, sunn hemp, and velvetbean. HortScience, v. 42, n. 2, p. 289-293, 2007.

BARROSO, A. A. M.; HIJANO, N.; ALVES, P. L. C. A. Biologia das plantas daninhas resistentes ao glyphosate no Brasil. Revista Cerrado Agrociências, v. 8, n. 1, p. 75 87, 2017.

BARROSO, A. A. M.; YAMAUTI, M. S.; ALVES, P. L. C. A. Interference between weed species and two bean cultivars in two times of sowing. Bragantia, v. 69, n. 3, p. 609-616, 2010.

BERGTOLD, J. S.; RAMSEY, S.; MADDY, L.; WILLIAMS, J. R. A review of economic considerations for cover crops as a conservation practice. Renewable Agriculture and Food Systems, v. 32, n. 1, p. 1-15, 2017.

BORGES, W. L. B.; FREITAS, R. S.; MATEUS, G. P.; SÁ, M. E.; ALVES, M. C. Supressão de plantas daninhas utilizando plantas de cobertura do solo. Planta Daninha, v. 32, n. 4, p. 755-763, 2014.

BORGHI, E.; COSTA, N. V.; CRUSCIOL, C. A. C.; MATEUS, G. P. Influência da distribuição espacial do milho e da Brachiaria brizantha consorciados sobre a população de plantas daninhas em sistema plantio direto na palha. Planta Daninha, v. 26, n. 3, p. 559-568, 2008.

BUHLER, D. D.; MAXWELL, B. D. Seed separation and enumeration from soil using $\mathrm{K}_{2} \mathrm{CO}_{3}$ centrifugation and image analysis. Weed Science, v. 41, n. 2, p. 298302, 1993.

BYBEE-FINLEY, K. A.; MIRSKY, S. B.; RYAN, M. R. Crop biomass not species richness drives weed suppression in warm-season annual grass-legume intercrops in the northeast. Weed Science, v. 65, n. 5, p. 669-680, 2017.
CARDINA, J.; HERMS, C. P.; DOOHAN, D. J. Crop rotation and tillage system effects on weed seedbanks. Weed Science, v. 50, n. 4, p. 448-460, 2002.

CARDOSO, I. S.; JAKELAITIS, A.; SOARES, M. P.; ARAÚJO, V. T. de; CABRAL, P. H. R. Weed community composition in different agro-systems. Comunicata Scientiae, v. 8, n. 1, p. 139-148, 2017.

CHAUHAN, B. S.; JOHNSON, D. E. Influence of tillage systems on weed seedling emergence pattern in rainfed rice. Soil and Tillage Research, v. 106, n. 1, p. 15-21, 2009.

D’AMICO-DAMIÃO, V.; NUNES, H. D.; COUTO JUNIOR, P. A.; LEMOS, L. B. Straw type and nitrogen fertilization influence winter common bean yield and quality. International Journal of Plant Production, v. 14, n. 1, p. 703-712, 2020.

DARMENCY, H.; COLBACH, N.; LE-CORRE, V. Relationship between weed dormancy and herbicide rotations: implications in resistance evolution. Pest Management Science, v. 73, n. 10, p. 1994-1999, 2017.

FENG, L.; CHEN, G. Q.; TIAN, X. S.; YANG, H. M.; YUE, M. F.; YANG, C. H. The hotter the weather, the greater the infestation of Portulaca oleracea: opportunistic life-history traits in a serious weed. Weed Research, v. 55, n. 4, p. 396-405, 2015.

GALVAN, J.; RIZZARDI, M. A.; PERUZZO, S. T.; OVEJERO, R. F. Evolution of ryegrass seed banks depending on soil tillage and crops. Planta Daninha, v. 33, n. 2, p. 183-191, 2015.

GAZZIERO, D. L. P.; ADEGAS, F. S.; SILVA, A. F.; CONCENÇO, G. Estimating yield losses in soybean due to sourgrass interference. Planta Daninha, v. 37, e019190835, 2019.

GHEREKHLOO, J.; MORENO, P. T. M.; DE-LACRUZ, R. A.; GONZÁLEZ, E. S.; HIPOLITO, H. E. C.; VALENZUELA, J. A. D.; PRADO, R. Pro-106-Ser mutation and EPSPS overexpression acting together simultaneously in glyphosate-resistant goosegrass (Eleusine indica). Scientific Reports, v. 7, n. 1, p. 67026712, 2017.

GOMES JUNIOR, F. G.; CHRISTOFFOLETI, P. J. Biologia e manejo de plantas daninhas em áreas de plantio direto. Planta Daninha, v. 26, n. 4, p. 789-798, 2008.

JAVAID, M. M.; BHAN, M.; JOHNSON, J. V.; RATHINASABAPATHI, B.; CHASE, C. A. Biological and chemical characterizations of allelopathic potential of diverse accessions of the cover crop sunn hemp. Journal of the American Society for Horticultural Science, v. 140, n. 6, p. 532-541, 2015.

KISSMANN, K. G.; GROTH, D. Plantas infestantes e nocivas. 2. ed. São Paulo: Basf, 1999. 
LIMA, S. F.; TIMOSSI, P. C.; ALMEIDA, D. P.; SILVA, U. R. da. Fitossociologia de plantas daninhas em convivência com plantas de cobertura. Revista Caatinga, v. 27, n. 2, p. 37-47, 2014.

MARTIN-GUAY, M. O.; PAQUETTE, A.; DUPRAS, J.; RIVEST, D. The new green revolution: sustainable intensification of agriculture by intercropping. Science of the Total Environment, v. 615, n. 1, p. 767-772, 2018.

MASIN, R.; ZUIN, M. C.; OTTO, S.; ZANIN, G. Seed longevity and dormancy of four summer annual grass weeds in turf. Weed Research, v. 46, n. 5, p. 362-370, 2006.

MOSJIDIS, J. A.; WEHTJE, G. Weed control in sunn hemp and its ability to suppress weed growth. Crop Protection, v. 30, n. 1, p. 70-73, 2011.

MUELLER-DOMBOIS, D.; ELlEMBERG, H. Aims and methods of vegetation ecology. New York: Willey \& Sons, 1974

MURPHY, S. D.; CLEMENTS, D. R.; BELAOUSSOFF, S.; KEVAN, P. G.; SWANTON, C. J. Promotion of weed species diversity and reduction of weed seedbanks with conservation tillage and crop rotation. Weed Science, v. 54, n. 1, p. 69-77, 2006.

NOGUEIRA, C. H. P. Seletividade dos herbicidas bentazon e nicosulfuron para Crotalaria juncea $e$ Crotalaria spectabilis em consórcio com a cultura do milho. 2015. Dissertação (Mestrado em Produção Vegetal) - Universidade Estadual Paulista, Jaboticabal, 2015.
PINTO-COELHO, R. M. Fundamentos em ecologia. Porto Alegre: Artes Médicas Sul, 2000.

TAKANO, H. K.; OLIVEIRA JUNIOR, R. S.; CONSTANTIN, J.; BRAZ, G.; GHENO, E. A. Goosegrass resistant to glyphosate in Brazil. Planta Daninha, v. 35, n. 1, p. 1-9, 2017.

TEIXEIRA, I. R.; SILVA, R. P.; SILVA, A. G.; FREITAS, R. S. Competição entre feijoeiros e plantas daninhas em função do tipo de crescimento dos cultivares. Planta Daninha, v. 27, n. 2, p. 235-240, 2009.

TREZZI, M. M.; VIDAL, R. A.; PATEL, F.; MIOTTO JUNIOR, E.; DEBASTIANI, F.; BALBINOT JUNIOR, A. A.; MOSQUEN, R. Impact of Conyza bonariensis density and establishment period on soyabean grain yield, yield components and economic threshold. Weed Research, v. 55, n. 1, p. $34-41,2015$.

UNITED STATES DEPARTMENT OF AGRICULTURE (USDA). Soil Survey Staff. Keys to soil taxonomy. 12. ed. Washington, DC: USDA, 2014.

VARGAS, L. A.; PASSOS, A. M.; MARCÍLIO, V. A.; BRUGNERA, F. A.; LEITE, V. P.; COSTA, R. S. Soil seed bank phytosociology in no-tillage systems in the southwestern Amazon region. American Journal of Plant Sciences, v. 8, n. 1, p. 3399-3413, 2017.

WEBSTER, T. M.; CARDINA, J.; WHITE, A. D. Weed seed rain, soil seedbanks, and seedling recruitment in no-tillage crop rotations. Weed Science, v. 51, n. 4, p. 569$575,2003$. 